\title{
Construcción y funcionalidad del inmigrante en los relatos «El candelabro de plata» de Abelardo Castillo y «El checoslovaco» de Alberto Laiseca*
}

\section{Introducción}

La literatura argentina se ha encargado de confirmar aquella idea borgeana de que la tradición argentina es el universo ${ }^{1}$ con su permeabilidad hacia autores, obras y tópicos de culturas extranjeras, cuya apropiación o puesta en escena también puede ofrecer, en numerosas ocasiones, algún indicio a la hora de intentar definir o dar cuenta de la propia identidad nacional. Aunque esa interrelación a nivel general ya fue estudiada, por ejemplo, por Gramuglio ${ }^{2}$, considero relevante establecer relaciones de análisis entre una serie de autores argentinos que han abordado en su ficción algunos elementos asociados al ámbito de lo checoslovaco en particular. El caso más trascendente es el del propio Borges cuya adaptación de Praga bajo la ocupación nazi responde a un claro interés cultural a partir de su lectura de Kafka y Gustav Meyrink. Una motivación semejante tiene en Respiración artificial (1980) de Ricardo Piglia aquel encuentro, en una célebre cafetería praguense ${ }^{3}$, entre Hitler y Kafka que tiene un rol preponderante en la novela al coincidir con algo que, en términos kafkianos, podríamos definir como «el punto sin retorno» de fracaso y marginalidad que experimenta el personaje polaco Tardewski, muy vinculado, a su vez, al escritor Witold Gombrowicz. Y si bien Kafka es un puente constante entre la cultura praguense y la

* La preparación y publicación de este trabajo ha sido posible gracias a la financiación del proyecto de investigación «Actualización de las perspectivas y metodologías de investigación en la lingüística, la literatura y la cultura de los países de lengua romance» (IGA_FF_2021_022) otorgado a la Universidad Palacký de Olomouc por el Ministerio de Educación, Juventud y Deporte de la República Checa.

1 «Todo lo que ha ocurrido en Europa, los dramáticos acontecimientos de los últimos años de Europa, han resonado profundamente aquí. El hecho de que una persona fuera partidaria de los franquistas o de los republicanos durante la guerra civil española, o fuera partidaria de los nazis o de los aliados, ha determinado en muchos casos peleas y distanciamientos muy graves. Esto no ocurriría si no estuviéramos desvinculados de Europa» (Borges, 1932, 81).

2 Gramuglio, María Teresa. Nacionalismo y cosmopolitismo en la literatura argentina, Buenos Aires, Rosario, Editorial Municipal de Rosario, 2013.

3 Es interesante el hecho de que el nombre real de la cafetería (kavárna) es "Arco» mientras que en la novela leemos «Arcos», como si en esa «s» excedente estuviera cifrada la idea de construcción literaria, lo cual sirve para reafirmar, una y otra vez, que en los textos literarios no debería hablarse de ámbitos reales sino de sitios que se originan, también, como consecuencia de la inventiva de los autores.

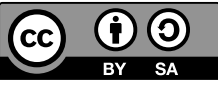

DOI:10.4312/ars.15.2.201-219 
literatura argentina que, mucho más acá en el tiempo, se advierte, por ejemplo, en $E l$ hijo judío (2018) de Daniel Guebel, no es el único aspecto que la literatura argentina aborda de la cultura checoslovaca. Por ejemplo, la leyenda judía del Golem ${ }^{4}$ aparece en varios cuentos de Ana María Shua, en un relato de Juan-Jacobo Bajarlía incluido en Historias de monstruos y en la novela juvenil El loco de Praga (2001) de Lucía Laragione; mientras que el emblemático Puente de Carlos y las huellas de la Praga comunista ocupan un fuerte lugar simbólico en Frenesí, la novela de José María Brindisi publicada en 2006. En ese contexto, la propuesta de este artículo, que intenta hacer un aporte al área de las literaturas comparadas y se enmarca en una tesis doctoral sobre la literatura argentina vinculada a lo praguense y lo checo en general, es realizar un análisis comparativo de los relatos «El candelabro de plata» de Abelardo Castillo $\mathrm{y}$ «El checoslovaco» de Alberto Laiseca, incluidos en sus respectivos primeros libros de cuentos: Las otras puertas (1961) y Matando enanos a garrotazos (1982). Dentro de ese corpus no tan reducido, como podría parecer a simple vista, de literatura argentina con temática checa/checoslovaca se trata de dos textos representativos y relativamente breves que, si bien fueron analizados de manera aislada, resulta útil leer en conjunto ya que, gracias a su rico entramado de semejanzas y diferencias, pueden aportar ideas interesantes respecto a lo que es el objetivo de este trabajo: entender de qué manera los autores argentinos construyen la figura del inmigrante checoslovaco, pero también indagar qué tipo de factores motivan su inclusión y si las imágenes acerca de ese país en particular pueden brindar algunas características del contexto de aparición de cada relato.

\section{Contextos literarios}

El contexto de aparición de «El candelabro de plata» coincide con los inicios del boom latinoamericano, esa época de gran debate político, clima de vanguardia, renovación del lenguaje literario y sensación de intenso cambio que inauguró la revolución cubana en 1959 y suele periodizarse con pocos años de diferencia. Por ejemplo, Sánchez (2009) lo ubica, precisamente, entre 1963, con la publicación de La ciudad y los perros de Vargas Llosa, y 1972, con la aparición de América Latina en su literatura, obra crítica coordinada por César Fernández Moreno. Aunque tuvo su auge en 1967 con el éxito sin precedentes de Cien años de soledad, las innovaciones formales de este período no son del todo aisladas ya que encuentran ciertos antecedentes en la década del cuarenta, en la obra de autores como Borges y Bioy Casares, en lo que respecta al campo literario argentino.

4 Si bien no es una leyenda exclusiva de Praga ya que una primera versión lo sitúa en la ciudad polaca de Chelm, es indudable que la versión praguense que tiene como figura creadora al rabino Löw es la más conocida y adaptada por el cine y la literatura. 
Sin embargo, las novedades terminaron de confluir en la década del sesenta, y especialmente en la novela, a partir de un complejo entramado de condiciones estéticas, políticas, institucionales, editoriales y también críticas, cuyos fuertes lazos de pertenencia continental (promovidos, especialmente, desde Cuba) y cierta apertura hacia temáticas universales y escenarios urbanos marcaron una fuerte oposición respecto a nacionalismos, regionalismos y espacios rurales que caracterizaban la literatura de épocas anteriores. Por otro lado, esas innovaciones técnicas y modernistas que, en parte, provenían de autores norteamericanos como Faulkner y apuntaban a cierta refundación del realismo, se oponían también al arte prescriptivo y normalizador de la Unión Soviética. Si bien no dejaba de establecer lazos con la sociedad (por ejemplo, despertando la conciencia de los lectores) la literatura debía mantener también sus propias reglas. En definitiva, el impulso de época hacia lo nuevo no se reducía a la lucha política, sino que requería también un cambio estético.

Abelardo Castillo (1935-2017), quien describió esa búsqueda literaria como la necesidad de «captar zonas más hondas de la realidad» representa la figura del escritor-intelectual comprometido en tanto agente de transformación, en el sentido en que lo explica Claudia Gilman, es decir, como consecuencia de una serie de factores propios de esa época, entre los cuales menciona «la dominancia del progresismo político en el campo de las elites culturales; la hipótesis generalizada acerca de la inmanencia de la revolución mundial; el debate sobre los nuevos 'sujetos revolucionarios' [...]; y el interés por los asuntos públicos» (Gilman, 2003, 29).

Aparte de su obra literaria que incluye, además de libros de cuentos, novelas importantes como El que tiene sed (1985) y Crónica de un iniciado (1991), ensayos y obras de teatro como El otro Judas (1961) e Israfel (1964), Abelardo Castillo es también un intelectual influido por Sartre. Miembro no dogmático del Partido Comunista argentino, Castillo tuvo una intensa participación en debates intelectuales, políticos y literarios a partir de su rol como director de tres revistas que tuvieron trascendencia en el país: El grillo de papel (1959-1960), El escarabajo de oro (1961-1974) y El Ornitorrinco (1977-1986). En tanto herramientas fundamentales de articulación entre cultura y política, las dos primeras estuvieron entre las publicaciones que más interactuaron con la revista de Casa de las Américas. Tal como hace ver Gilman, muchas de esas publicaciones nacían por «la necesidad de hacer avanzar el arte del mismo modo que la vanguardia política hacía avanzar las condiciones de la revolución, es decir, sin dejar de utilizar todos los instrumentos y conquistas del arte contemporáneo» (Gilman, 2003, 144). En otras palabras, lejos del panfleto político, lo comprometido no debía ser tanto la obra literaria como sí el autor.

A través de esa importante plataforma, Abelardo Castillo intervino, desde su posición ideológica de izquierda, también en esa serie de discusiones en torno al ser nacional que, en 1946, habían surgido como consecuencia del primer gobierno peronista y, 
en cierta forma, continuaron durante el posterior exilio de su líder político tras el golpe de 1955. Precisamente, en el número 23-24 correspondiente al mes de septiembre de 1964, es decir, dos años después de la publicación del cuento que nos ocupa, la revista El escarabajo de oro incluye un relato de Abelardo Castillo llamado «Los muertos de Piedra Negra». La historia se centra en un levantamiento de trabajadores peronistas contra un cuartel militar en la Provincia de Buenos aires que ocurre en 1956, es decir, poco después de la Revolución Libertadora y el mismo año de los fusilamientos de José León Suárez, tema abordado por Rodolfo Walsh en Operación Masacre. Aunque planteado en términos de ficción, el cuento ofrece un contexto muy reconocible en el que no se elude el clima de proscripción, la represión militar, las pintadas clandestinas en las paredes y, sobre todo, el grito profundamente contenido de «Viva Perón» que estructura este relato en el que, además, se pone en juego el complejo entramado de traiciones y lealtades tan afín al peronismo. Si bien se trata de un cuento lo suficientemente complejo como para hacer lecturas lineales, al menos una de las descripciones sobre el coronel que lidera el operativo parece coincidir, en algún punto, con ese alejamiento de la dicotomía o tercera posición en la que se mantuvo Abelardo Castillo respecto al movimiento social y político más influyente del siglo XX argentino: «Lago, que nunca había sido peronista, ni lo era, pero que no se iba a poner a explicarles a unos carretilleros que restituir el honor de la Nación exige, de sus hombres, ciertas decisiones [...]» (Castillo, 2003, 104). El propio Abelardo Castillo reveló, en una entrevista con Página/12 (Castillo, 2011), la razón por la que fue expulsado de la escuela secundaria, al manchar con tinta un retrato de Perón y Evita el día anterior a la visita de la interventora, una anécdota que, al mismo tiempo que evidencia esa tercera posición neutral (al menos a nivel consciente), no deja de mostrar cómo el peronismo ejercía, en esa época, una influencia insoslayable ${ }^{5}$.

Por su parte, el contexto de aparición de «El checoslovaco» en la última etapa de la dictadura militar, pero, a su vez, en plena Guerra de Malvinas muestra, respecto a la época del boom, un clima político diametralmente opuesto debido a tantos años de censura, desaparición sistemática de personas y terrorismo de Estado. Pero, a la vez, existe cierto consenso en la crítica que se trata de una época que empieza a instaurar en lo literario un mayor desborde imaginativo y referencias mucho menos directas y más tortuosas respecto a la realidad, gran concentración en el plano del lenguaje y cierta transgresión de los tópicos literarios que posibilitaron la irrupción de algunas estéticas vanguardistas vinculadas a la revista Literal (1973-1977), como las de Osvaldo Lamborghini, Luis Gusmán y César Aira, de quien el estilo de Laiseca parece abrevar. Ya durante la década del ochenta, tal como afirma Elsa Drucaroff, aparecen varias novelas con características similares de César Aira, el propio Laiseca y otros escritores como

5 «No fue un acto político, fue algo inconsciente, pero se tomó como una manifestación anárquica o comunista porque el tintero era de tinta roja,» precisaba Abelardo Castillo en la entrevista. 
Sergio Chejfec, Daniel Guebel y Alan Pauls: «Aira es el primero en proponer tramas donde lo exótico se fusiona con lo vernáculo en forma delirante» (Drucaroff, 2011, 55). Luego agrega Drucaroff que, en esos libros que parecen defender la autonomía del significante y esquivar todo conflicto social oponiéndose así al característico cruce de literatura y política de las generaciones anteriores, priman escenarios y referencias tan distantes como Egipto, China, Grecia o Malasia.

Por otro lado, Laiseca también podría pensarse como heredero de Roberto Arlt, en lo que respecta a cierta idea de lo periférico, salvaje y esa tradición de «mala escritura» que se opone a los principios canónicos de la alta literatura borgeana. Lo interesante es que, durante la década del ochenta, las nuevas generaciones literarias del post-Boom ejercen un particular distanciamiento respecto a la obra de Borges: hiperbolizando, por ejemplo, aquella idea de la tradición universal. Es decir, lo que en la época del boom significaba salir de regionalismo para abrir cierta ventana a lo universal, en esta época se transforma, directamente, en una serie de referencias y locaciones absolutamente exóticas, desbordantes, absurdas y delirantes como veremos, en efecto, en el relato «El checoslovaco». Pero en el caso particular de Alberto Laiseca también puede establecerse, en ese mismo sentido, una relación interesante con el peronismo. Más allá de que suele mencionarse la constancia de referencias antisindicalistas en algunas de sus obras, el vínculo más claro de Laiseca no es tanto con el peronismo de la década del cuarenta y su posterior proscripción, sino más bien con ese período de decadencia y pérdida absoluta del rumbo que transcurre entre 1973 y 1976. En especial, lo que parece interesar (o, mejor dicho, obsesionar) a Laiseca es, por un lado, la Triple A y, al mismo tiempo, la inefable figura del secretario privado de Perón, José López Rega. En efecto, Su turno para morir (1976), más allá de sus ropajes de policial norteamericano, no deja de remitir, en clave alegórica, a los crímenes parapoliciales de la Triple A, mientras que el propio López Rega aparece, en numerosas ocasiones, como personaje en su novela El jardín de las máquinas parlantes (1993) con el nombre ligeramente modificado de López Fecia (un primer ministro maléfico) ${ }^{6}$, constituyendo acaso la referencia explícita más directa a la realidad política en toda la obra de Laiseca al enhebrar una parodia alucinada de esa última etapa del peronismo. De hecho, el propio Perón es mencionado como «el Quétzal» y el movimiento, en su conjunto, como «el quetzalismo» ${ }^{7}$.

Por supuesto, no se trata de un hecho aislado sino de un elemento que corresponde a todo un sistema de representación del Brujo como un individuo oscuro y

6 «Me olvidé de decirte que... el Gobierno de Guatimotzín, por orden de José López Fecia, acaba de triplicar los impuestos ...» (Laiseca, 1993, 620).

7 «Se le habrá muerto el astral y también su abuela, pero sigue bien vivo y Primer Ministro. Está convencido de que él es el Rasputín del quetzalismo. Se lo cree y todo. Y lo peor es que no es el único en creérselo. Los otros días le dijo al Quétzal: «Si yo muero, o si soy defenestrado, será el fin del Movimiento. Soy el Escudo contra el cual se estrellan las hordas comunistas» (Laiseca, 1993, 716). 
tenebroso que aparece, por ejemplo, en Cola de lagartija de Luisa Valenzuela y en La novela de Perón y Santa Evita de Tomás Eloy Martínez. En definitiva, esa constelación de fascismo, magia, ocultismo, poder y terror político trabajada, a partir de la figura de López Rega, en una de las novelas más importantes de Laiseca, tal vez encuentre cierto germen en el cuento que, en este artículo, nos ocupa.

Por otro lado, la notable amplitud en las propuestas estéticas de ambos autores también se observa en sus distintas vías de acceso al campo literario. En comparación con Abelardo Castillo, Alberto Laiseca (1941-2016) tuvo una inserción más gradual y, en algún punto, excéntrica ya que empezó a tener visibilidad, en la televisión, como un llamativo presentador de cuentos de terror. A la par, fue consolidando esas apariciones públicas con una obra extensa conformada, sobre todo, por novelas y, en menor medida, libros de cuentos. Su estilo literario, definido por él mismo como «realismo delirante», está mucho más asociado, otra vez, a los desbordes, lo deforme y lo monstruoso. Sin ir más lejos, un punto bisagra en su obra es la novela Los sorias (1998), famosa incluso antes de publicarse por sus casi mil cuatrocientas páginas. Considerada una de las más extensas de la literatura argentina, se publicó con un prólogo de Ricardo Piglia que remarca, otra vez, su filiación con Roberto Arlt, al definirla como «la mejor novela que se ha escrito en Argentina desde Los siete locos» (Piglia, 2004, 9).

Pero más allá de las diferencias señaladas entre ambos contextos literarios, también pueden establecerse algunas semejanzas entre estos dos autores que, por ejemplo, fueron formadores en sus respectivos talleres literarios. Por otro lado, aunque muy distintas en algún punto, sus propuestas también están emparentadas, tal como explica Agustín Conde de Boeck (2017, 487).

Partiendo de este Laiseca kafkeano-jarryeano, podría rescatarse también una serie de parentescos particulares, donde, vía Poe, el realismo delirante entronca con Horacio Quiroga y Abelardo Castillo (por ejemplo, el sistema de similitudes entre El jardín de las máquinas parlantes y Crónica de un iniciado).

En cuanto a los relatos que nos ocupan, consideramos que es posible advertir notables diferencias en el tono y estilo de escritura, pero también algunas semejanzas en lo que respecta al exotismo y la marginalidad que destilan ambos personajes checoslovacos y su inclusión en el relato, aunque el signo de esa utilización resulte, otra vez, casi antagónico.

\section{Herramientas teóricas}

En este artículo utilizo algunos dispositivos teóricos de la imagología, disciplina de las literaturas comparadas que analiza las distintas imágenes sobre nacionalidades en ficciones literarias. Entre los conceptos de la imagología que pueden resultar útiles para 
este tipo de análisis está la clásica distinción que retoman de Aristóteles entre «diferencia específica» $\mathrm{y}$ «género próximo». Mientras la primera abarca el conjunto de características concretas que determinado texto le atribuye al país o ciudadano de un país en particular, la noción de «género próximo» engloba a una zona atravesada por distintas nacionalidades que, por algún motivo, aparecen poco diferenciadas. Otro concepto relevante de la imagología será el de «exotismo», desarrollado exhaustivamente por Joep Leerssen, quien, en primer lugar, afirma que el exotismo puede llevar a la incomprensión y al miedo, pero también a la admiración, y esa apreciación positiva se opondría al etnocentrismo cuando el país extranjero es valorado positivamente. Pero enseguida aclara que el exotismo también puede ser una cara más del etnocentrismo ya que esa cultura ajena puede ser apreciada, exclusivamente, por aquellos aspectos que se salen del estándar propio. En todo caso, Leerssen ofrece una definición de este concepto muy apropiada para leer nuestros relatos: «Lugar exótico es donde las leyes de la normalidad, el realismo y lo mundano se suspenden en favor de lo extraño, distinto e impredecible dando lugar, a veces, a eventos mágicos o sobrenaturales» (Beller-Leerssen, 2007, 325).

Además, Joep Leerssen y Carlos Reijnen resumen, nada menos, que la producción de imágenes que inspiró la capital checa entre el siglo XIX y el siglo XX.

Durante el siglo XIX Praga obtuvo la reputación literaria de una ciudad medieval, gótica, oscura y encantadora, teñida de un exotismo eslavo, centroeuropeo. Esa imagen persistiría durante el siglo XX (incluso en las novelas de espías de la Guerra Fría y la década del noventa), al ser difundida por El golem (2015) de Gustav Meyrink y la asociación de la ciudad con Franz Kafka (Beller-Leerssen, 2007, 137).

Como ya veremos, esa caracterización de Praga se ajusta muy bien a las imágenes construidas por muchos de los textos literarios argentinos, $y$, en especial, los dos relatos que nos ocupan: es que, a diferencia de las ciudades españolas e italianas, más cercanas a nivel cultural, Praga va a aparecer ligada en estos textos a la idea de exotismo.

El argentino César Aira $(1993,73)$ ofrece también una perspectiva del término «exotismo», aunque vinculada a la producción literaria en Argentina y, al mismo tiempo, en sintonía con la idea de «extrañamiento» de los formalistas rusos. Aira parte de que Montesquieu es el padre de la novela exótica ya que los protagonistas de Cartas persas ofrecen, en tanto extranjeros, una mirada completamente distinta de Europa. Luego remarca que esos personajes persas son un «como si» que, en su opinión, marca el origen de la novela moderna. En este caso, lo exótico no se emplea para nombrar lo desconocido y lejano sino, por el contrario, para ver con ojos distintos lo propio o incluso poder 
nombrarlo. La paradoja es que dicho exotismo, según Aira, tiene como objetivo dar fundamento a esa característica azarosa que es contar con determinada nacionalidad.

La literatura es el medio por el que un brasileño se hace brasileño, un argentino, argentino. Es lo necesario para que el Brasil se transforme en el Brasil, para que la Argentina llegue a ser la Argentina. En última instancia, para que el mundo se transforme en mundo (Aira, 1991, 79).

La idea presenta algunos puntos en común con otra distinción relevante de la imagología que es el par «heteroimagotipos» y «autoimagotipos».

Los heteroimagotipos son las imágenes que un Yo elabora de un Otro, construidas por analogía con las imágenes que tiene de sí mismo. En sentido inverso y complementario, los autoimagotipos son las imágenes del Yo que surgen del contraste con las imágenes del Otro, a partir de las cuales el Yo se identifica (Pérez Gras, 2018, 42).

Esa distinción también resulta útil a la hora de pensar algunos textos argentinos sobre «lo praguense», «lo checo» o «lo checoslovaco» porque ambas modalidades de imágenes parecen estar todo el tiempo en relación dialéctica, es decir, los atributos que se construyen sobre naciones ajenas pueden hablar también de la cultura propia.

Por último, debido a su relevancia indudable en la literatura argentina (Martín Prieto, 2016, 420) señala que «concentra todos los procedimientos - alegoría, opinión política, cruces con el género policial, utilización del pasado como clave para leer el presente»-), su pertinencia temática y cronológica (ya que fue publicado entre los dos relatos que nos ocupan), e incluso por su propio componente de crítica literaria combinada con ficción, consideramos que Respiración artificial (1980) de Ricardo Piglia también puede ofrecer algunas claves en nuestro análisis. Sin ir más lejos en el diálogo que mantienen Tardewski y Renzi se define el término «ostranenie», es decir, esa forma de mirar desde afuera, con perspectiva, para acceder a la realidad más allá del velo de lo habitual como «la mirada del turista, pero también, en última instancia, la mirada del filósofo» (Piglia, 1980, 2816). En sintonía con la cita anterior de Aira, la frase remite también al verdadero agente de esa mirada extrañada y, a la vez, lúcida que es, al menos para Tardewski, la figura del fracasado, o sea él mismo. No es casual que, en Respiración artificial, esa figura del inmigrante o el exiliado errante y al margen de la sociedad aparece muy vinculada a eso que recorre todo el libro y es lo que se denomina «el origen de la historia», "eso que viene desde el fondo mismo de la historia de la patria, a la vez único y múltiple» (Piglia, 1980, 727). 


\section{4 «El candelabro de plata» de Abelardo Castillo}

En ambos relatos nos encontramos con protagonistas algo marginales y sin mucho arraigo, a pesar de que llevan un tiempo considerable en Argentina: Franta arribó hace treinta años mientras que Stepan hace poco menos de veinte. En ese sentido, podríamos pensar que, al igual que el personaje de Tardewski en Respiración artificial estos dos inmigrantes checoslovacos encarnan la paradoja de ser aves de paso que permanecen en el mismo lugar durante muchos años. Sin embargo, en la construcción de ambos personajes se perciben, en efecto, muchas diferencias. Franta, el checoslovaco de Abelardo Castillo, a quien el narrador invita a su casa para compartir un fatídico festejo de Nochebuena luego de encontrarlo en una sórdida cantina en pleno puerto de Buenos Aires, es sereno, respetuoso y hasta condescendiente: se dirige a su interlocutor como «señor». Stepan, el personaje de Alberto Laiseca, por el contrario, es cruel, manipulador y violento: un ingeniero que se dedica a torturar a su esposa, a quien consigue inocularle una enfermedad mediante agresiones permanentes con el arma del lenguaje. En cambio, la palabra del checoslovaco del cuento de Abelardo Castillo no solo no tiene por objetivo maltratar a su interlocutor, sino que, por el contrario, busca (según explica el propio narrador de la historia), confesarse: «Acaso yo le había preguntado algo, o acaso, rota la frialdad del primer momento (para esa hora ya estábamos bastante borrachos), la confesión surgió por sí misma» (Castillo, 2012, 89). Sin embargo, eso que el narrador define, de manera arbitraria como «confesión», en realidad es el relato que hace el checoslovaco sobre sus orígenes, su tierra y aquellos seres queridos de quienes, en su momento, se tuvo que despedir al llegar a la Argentina como inmigrante.

El hecho es que habló. Habló de su país, de una pequeña aldea perdida entre colinas grises, de una mujer rubia cuyos ojos -así lo dijo- eran transparentes y azules como el cielo del mediodía. Habló de un muchachito, también rubio, también de ojos azules (Castillo, 2012, 89).

Su discurso aparece teñido de un fuerte cliché: el de que los habitantes de aquella parte del mundo, en contraste con los de Argentina, son rubios y de ojos celestes. Se trata de un cliché vinculado con la idea de exotismo desarrollada por Leerssen en tanto funciona como un atributo que sorprende al propio Franta, lo cual resulta curioso teniendo en cuenta que también tiene «unos ojos celestes, clarísimos» y, sin embargo, él mismo establece la analogía entre la tonalidad del cielo y el color de ojos de quien era su mujer, como si los años que lleva viviendo lejos de su país de origen hubieran incrementado, además de la nostalgia, su asombro respecto a los rasgos físicos de sus seres queridos. Ahora bien, mientras en el relato de Laiseca la palabra es un arma cruel que detenta el inmigrante para torturar a su propia esposa, en el de Castillo es el narrador 
argentino quien le hace creer a Franta su falsa intención de ayudarlo a volver a su país y, por lo tanto, recuperar su dignidad perdida. Sin embargo, a diferencia de lo que sucede en el relato de Laiseca, la crueldad que ejerce el personaje argentino sobre el checoslovaco no se va a haber plasmada al nivel del lenguaje que, de hecho, mantiene, incluso en los momentos más álgidos del cuento, cierta armonía y hasta formalidad en línea con el ligero anacronismo que el protagonista le atribuye al candelabro que da título al relato. En efecto, en el estudio crítico que sirve como prólogo a la edición de sus cuentos completos, Marta Morello-Frosch entiende que la crueldad de este relato de Abelardo Castillo, lejos de ser gratuita, tiene como propósito restituir la humanidad del checoslovaco.

[...] la posibilidad de rectificar este destino desviado es suficiente para restituir al viejo, por unos minutos, a la condición humana: pierde su tono suplicante y deja de rendir pleitesía al «señor» que le ofrece ayuda (Morello-Frosch, 2012, 17).

A tono con el contexto vanguardista y esa fuerte sensación de transformación que, tras la revolución cubana, caracteriza la literatura latinoamericana de los años sesenta es interesante advertir que la inclusión de ese checoslovaco no deja de tener que ver con cierta apertura hacia lo universal, a través de una figura muy recurrente en Argentina (la del inmigrante) pero que, en este caso, no proviene de los países más habituales (España e Italia) sino de «la otra» Europa. Por otro lado, podría pensarse que, incluso a pesar del desenlace, el narrador no deja de provocar en el checoslovaco cierta toma de conciencia que podría llegar a vincularse, precisamente, con el clima de época (la inspiración de la revolución cubana, la descolonización africana y la resistencia de Vietnam, pero también, en algún punto, el horizonte de posibilidades inaugurado por el primer peronismo) aun cuando aquella búsqueda de autonomía aleja definitivamente a este relato del texto panfletario con moraleja. Es decir, tal vez en ese acto tan extremo como abrupto que termina ejerciendo el narrador sobre el checoslovaco pueda cifrarse la búsqueda de una literatura que, si bien debe conectar de alguna forma con la sociedad, también tiene que sustraerse a las normativas y mantener intactas sus propias reglas.

Resulta interesante, al respecto, que el narrador termina de pergeñar su decisión de asesinar a Franta justo a las doce, cuando la Nochebuena se transforma en navidad, durante un festejo en el que, en sintonía con aquel lejano país, parecen predominar ciertas notas de artificio o exotismo.

De pronto, la noche del puerto se hizo fiesta. En todos los muelles las sirenas empezaron a entonar su histérico salmodio y el cielo reventó de petardos. 
Brindamos con los ojos húmedos. Fuegos multicolores se abrían en las sombras, desparramando sobre el mundo extravagantes flores de artificio (Castillo, 2012).

Siguiendo los conceptos de la imagología podríamos considerar que, en esa dialéctica entre heteroimagotipos y autoimagotipos, el narrador parece fundar su propia identidad a partir del modo en que lo cataloga al checoslovaco de «miserable». Pero, además, aquel acto de resonancias mesiánicas que consiste en ayudarlo a «regresar» a su tierra resulta indispensable para poder definirse a sí mismo, una inquietud que aparece ya al comienzo del relato: «Pero al menos hoy he comprendido algo; lo he comprendido después de lo que pasó esta noche: soy un hombre bueno» (Castillo, 2012, 87). Esa misma bondad que libera al narrador del asco que - él mismo revela poco después - siente por su propia vida se la da el hecho de «hacer feliz a un miserable». Las menciones a la cultura checa en la obra de Abelardo Castillo, cuya premiada obra de teatro Israfel se representó en Checoslovaquia, no se reducen a este relato. En su novela El que tiene sed aparece a varios niveles: desde distintas referencias a Kafka y el Golem hasta la fascinación que ejerce en el protagonista Esteban Espósito la imagen del judío-eslavo Jakobo Fiksler. Pero volviendo a "El candelabro de plata», el exotismo y la creciente esperanza de ese inmigrante que proviene de una tierra distante a la que resulta difícil regresar, además de estar en sintonía con la búsqueda tanto universal como urbana de la época, y la respectiva sensación de posibilidad de cambio, parece tener una motivación también literaria; es decir, al servicio de la trama del relato: la inclusión de ese checoslovaco marginal le sirve al narrador argentino para construir su propia identidad, para transformarse en aquello que él quiere ver de sí mismo.

\section{5 «El checoslovaco» de Laiseca}

Uno de los diálogos de Respiración artificial, es este caso acerca de la parodia, puede arrojar luz sobre la principal diferencia de intencionalidad literaria que existe entre el cuento de Abelardo Castillo y el de Alberto Laiseca.

Renzi me dijo que estaba convencido de que ya no existían ni las experiencias, ni las aventuras. Ya no hay aventuras, me dijo, solo parodias. Pensaba, dijo, que las aventuras, hoy, no eran más que parodias. Porque, dijo, la parodia había dejado de ser, como pensaron en su momento los tipos de la banda de Tinianov, la señal del cambio literario para convertirse en el centro mismo de la vida moderna (Piglia, 1980, 1277). 
Es decir que, en sintonía con las diferencias que marcábamos entre los distintos campos literarios en que aparecieron estos relatos, donde antes podía haber un relato de expansión y aventura (aunque una aventura bastante siniestra como la del cuento de Castillo) ahora lo que predomina es la parodia, invadiendo cada uno de los gestos, acciones y pasiones, llegando a sustituir incluso a la propia historia. En efecto, casi en las antípodas de Franta, Stepan (el checoslovaco del relato de Laiseca), tortura a su mujer de una forma poco convencional: mediante el lenguaje que él utiliza como un arma asociada al extrañamiento que genera su articulación y empleo de una estructura gramatical distorsionada.

El checoslovaco hablaba mal el idioma, pero no pésimo como a veces hacía creer. Cuando decidió matar a su esposa exclusivamente con armas secretas, en su arsenal contaba con el lenguaje; como si éste fuera la más letal e importante de sus ojivas nucleares de cabezas múltiples (Laiseca, 2004, 120).

Al respecto, Lecercle (1990) se pregunta cómo es posible que un instrumento como el lenguaje, del que se espera que pueda comunicar a las personas, esté mezclado también de manera inextricable con las expresiones más violentas.

I have already suggested an answer when I noted that the structure of communication, involving as it does two participants, reproduces the structure of exchange of the closest and most tense emotional relationships, situations in which two is company with a deadly vengeance (Lecercle, 1990, 237).

Lecercle afirma que el lenguaje conlleva cierto grado de violencia no solo porque es un cuerpo de sonidos, sino porque además las palabras, como sucede en el caso de Stepan, cargan los efectos violentos del cuerpo del hablante. En sintonía con esta idea de materialidad, es interesante advertir que, en el relato de Laiseca, la crueldad ejercida mediante el lenguaje funciona más a nivel sintáctico que semántico. Algo que podemos comprobar, por ejemplo, cuando en el momento en que ella se pone a pelar papas, él se para detrás para decirle: «no puede retener cáscara». Si bien no deja de haber cierta asociación entre el significado de la frase y la acción de ella, lo que verdaderamente tortura a su mujer es el aspecto formal de esas locuciones: «decía en voz chirriante, mecánica, checoslovaca» (Laiseca, 2004, 121). Asimismo, poco después nos enteramos de que el checoslovaco amplía su frase, distorsionando aún más la gramática al formular: «Quien no puede retener cáscara, ella de mano cae» (Laiseca, 2004, 121). Es decir que, en sintonía con ese mayor foco en la materialidad del lenguaje que atribuíamos a los textos literarios de la época, en el discurso de Stepan lo formal tiene más relevancia que el contenido. En efecto, el plano semántico aparece tan relativizado 
que la crueldad de Stepan se potencia hasta el extremo cuando, paradójicamente, utiliza palabras bellas, refinadas o incluso «exóticas» como «lapislázuli»: «era terrible el contraste entre el bello vocablo elegido, y el feísmo de la falta de coordinación motora que calificaba» (Laiseca, 2004, 123). Es decir, la eficacia en esa arma mortal que es el lenguaje del checoslovaco - quien, no en vano, lleva como apodo «el ingeniero del tornillo filoso»- radica en el plano más material del discurso y, otra vez, como explicaba Lecercle, llega a tener un correlato físico. Por otro lado, esa condición de lo chirriante en su discurso podría vincularse con la supuesta fealdad estilística de Alberto Laiseca, que incluso inspiró una anécdota legendaria que lo erige como un escritor antiborgeano, tal como recupera Conde De Boeck.

En 1982, se difunde aquella célebre y semi-apócrifa anécdota según la cual Borges, frente a una pregunta donde le era mencionado Matando enanos a garrotazos, habría afirmado que jamás leería un libro con un gerundio en su título (remitiendo a la mala fama estilística de esta forma verbal). [...] Así, Alberto Laiseca, pasa a ser entonces el reverso de Borges, el dueño de una escritura «salvaje», entusiasta, pagana, opuesta a la distinción de la «alta» literatura (Conde de Boeck, 2017, 130).

Conde de Boeck entiende que el supuesto anti-borgeanismo resultó fundamental, años después, para convertir a Laiseca en un emblema de la generación literaria nucleada en torno al grupo Shangai ${ }^{8}$, la que, si bien Laiseca no perteneció formalmente, estaba muy interesada en oponer los delirios, excentricidades y exotismos de Laiseca al apolíneo estilo de Borges. Más allá de que, con el tiempo, ese anti-borgeanismo se fue moderando, no deja de ser relevante el paralelismo entre el «habla incorrecta» del checoslovaco y la «mala escritura» de Laiseca.

En cuanto a la violencia de su personaje, podríamos pensar que Laiseca, de quien marcamos su filiación con el autor de Los siete locos, abreva también en esa imagen de crueldad misógina de húngaros y polacos que Roberto Arlt mencionaba al referirse al proxenetismo de la Buenos Aires de su época, que tuvo un correlato real en la red Zwi Migdal durante las primeras décadas del siglo XX. Eso nos trae de nuevo la oposición entre «diferencia específica» $\mathrm{y}$ "género próximo»: quizás por motivos históricos y culturales para muchos autores argentinos las zonas de Europa Central y Europa del Este resultean más inaccesibles y, por consiguiente, sus países menos distinguibles que otras naciones de Europa Occidental. De hecho, más de diez años después, en su novela El jardín de las máquinas parlantes Laiseca trabajará también con el personaje de un inmigrante lituano y hasta con la figura de un golem con dos tornillos en el

8 Algunos de cuyos representantes son Daniel Guebel, Luis Chitarroni, Sergio Bizzio, Jorge Dorio y Martín Caparrós. 
cráneo, más parecido a la representación audiovisual de Frankenstein que a la leyenda de la judería de Praga ${ }^{9}$. En el mismo sentido, Laiseca solía reconocer en numerosas entrevistas su fascinación por la figura de Drácula y es como si ese legendario personaje de origen rumano atrajera casi por arrastre una tierra más o menos cercana a nivel geográfico como es Checoslovaquia. Por supuesto, esto no quiere decir que Laiseca confundiera ambos países, sino que sus límites simbólicos parecen ser más difusos y permeables. En efecto, la figura de Drácula aparece en este cuento encarnada en la relación vampírica que ejerce Stepan sobre su mujer: «Ella estaba cada vez más gorda, decaída y vieja. Él, por el contrario, parecía con ello cobrar nuevos bríos» (Laiseca, 2004, 119); pero también como referencia explícita.

Cierta vez el ingeniero del filoso tornillo fue al cine, a ver una película de terror. Quedó encantado. Siempre citaba ante sus escasos conocidos una frase de la cinta, que él atribuía al conde Drácula; Mi querido amigo: las mujeres no son un vicio, son una necesidad (Laiseca, 2004, 120).

Ahora bien, la crueldad de Stepan también es eficiente porque cuenta con cierto grado de seducción y encanto hacia Gloria que, por supuesto, termina siendo un mero combustible de su maldad. Lo interesante es que, otra vez, esta característica erótica tiene que ver con el lenguaje, que nuevamente es descrito en términos armamentísticos.

Empleaba armamentos pesados con objeto de erotizarla: tocaba con su lengua el agujero de la femenina oreja, le decía cosas increíbles, hablábale de que sus rodillas eran esto y aquello. Todo todo. Hasta que ella se olvidaba (Laiseca, 2004, 127).

Uno de esos momentos ocurre cuando Stepan le habla de Praga, su ciudad natal, y específicamente del río Moldava. Gracias a su poder evocador, ella, en una especie de rapto similar a la hipnosis o la hechicería, es capaz de trasladarse a aquella ciudad quedando a absoluta merced de él. Por supuesto, incluso entonces, el discurso del checoslovaco sigue siendo, a nivel formal, tan chirriante y dislocado como de costumbre.

Él se volvió intimista: «Me encanta este río. Muy caudaloso. Me recuerda al Moldava. De verdad cosa hermosa es, ver Moldava pasar bajo puentes de Praga. Muchas flores.» Ella lo escuchaba incrédula. Por un momento había visto el agua y los puentes, en aquella ciudad lejana y exótica (Laiseca, 2004, 126).

9 «Los gólem poseen sendos tornillos en las sienes. Sacando uno, el gólem queda desconectado; quitando ambos, cada parte de su cuerpo vuelve a su lugar de origen y se destruye» (Laiseca, 2013, 21). 
En sintonía con estos ejemplos, Lecercle asegura que la brujería depende inexorablemente del lenguaje: es el arma con que captura a sus víctimas. Incluso cuando es consciente de la violencia de su marido, Gloria no logra sustraerse al influjo de su hechicería, compuesta de unas buenas dosis de exotismo, a tal punto que termina enfermándose. Por último, otro elemento del discurso del checoslovaco que parece ejercer gran tortura en Gloria y nos puede resultar muy significativo en nuestro análisis es cierta construcción gramatical que poco tiene que ver con el idioma checo.

Gloria sabía que él tenía dificultades idiomáticas; pero comprendía muy bien que la pésima sintaxis de la frase había sido exagerada a propósito. En estos casos había que oírlo hasta el final si se quería comprender el sentido completo de la oración, que no era revelado salvo con la última palabra (Laiseca, 2004, 122).

Es interesante que ese rasgo lingüístico según el cual el sentido de una frase se revela recién con la última palabra, más que al idioma checo o eslovaco parece referir, sobre todo, al alemán que, por supuesto, forma parte de la imagen cultural praguense y, sobre todo, ocupa un lugar muy destacado en la representación que, desde Argentina, suele tenerse de la cultura praguense por el enorme influjo del escritor en lengua alemana Franz Kafka. Por otro lado, en uno de los pocos momentos en que Gloria logra expresar sus emociones de bronca, establece una analogía entre su marido y los nazis.

En una ocasión ella lo enfrentó. Le dijo con helada calma: «Te veo tan hijo de puta como esos nazis que asesinaron a los judíos. Sos un criminal de guerra frustrado. Esta casa es un campo de concentración. Por la cocina corren tus alambradas electrizadas y tus perros. Yo soy la prisionera y vos el SS. Sos un guacho» (Laiseca, 2004, 128).

Además de que, otra vez, clasificando a su marido como criminal de guerra nazi, Gloria termina definiéndose a sí misma como víctima, resulta casi imposible (aun teniendo en cuenta los laberínticos pliegues absurdos de la obra de Laiseca) no poner en relación esa frase con la violencia paramilitar de la Triple A (que, como vimos, fascinaba al escritor a partir, sobre todo, de la figura de López Rega) y, por supuesto, con la dictadura que, por ese entonces, estaba al frente del país. De hecho, hay varios indicios que, a través del doble sentido, parecen confirmar dicha asociación. Por ejemplo, cuando Gloria recibe una caja de bombones y protesta porque «estoy a régimen». Lo cierto es que, entre tanta parodia, hipérbole y desborde, todos elementos constitutivos del «realismo delirante» con que Laiseca definió su propio estilo, la inclusión exótica (en el sentido de Aira) de su personaje checoslovaco parece apuntar también a poner en palabras ese gran trauma propio que, por razones obvias, resultaba muy difícil nombrar en forma directa. 


\section{Conclusiones}

Dentro del corpus de obras argentinas vinculadas con la temática praguense o checa estos dos relatos relativamente breves de Abelardo Castillo y Alberto Laiseca, además de ser muy representativos, ofrecen una interesante perspectiva de comparación por su entramado de notables diferencias y posibles semejanzas. Mientras en el cuento de Laiseca notamos un fuerte predominio de lo paródico y lo distorsivo, Abelardo Castillo parece asignarle a su relato el mismo componente existencialista que caracteriza a toda su obra. Tal como vimos, las mismas diferencias se advierten en las distintas modalidades con las que ambos autores plantean la representación de lo extranjero: en Castillo no deja de haber una búsqueda de verosimilitud, que se advierte en algunas cuestiones como el nombre de su personaje y su gradual transformación al ilusionarse con regresar a su patria e incluso el cliché del color de ojos claro; mientras que, en el checoslovaco de Laiseca, parece haber algo más caricaturesco y absurdo, lo cual se percibe ya en su apodo ${ }^{10}$ y se confirma con la crueldad sin matices que ejerce contra su mujer mediante un absurdo uso de la gramática. No obstante, también encontramos semejanzas en la imagen marginal y exótica con que los autores configuran «lo checoslovaco». Por otro lado, ese mismo exotismo de los cuentos (tal vez un poco más en el de Laiseca que en el de Castillo) desarrolla un significante casi intercambiable, en el sentido en que la imagología habla de "género próximo». Esto quiere decir que, en algún punto, los relatos no sufrirían grandes modificaciones si, en lugar de checoslovacos, los personajes provinieran de sitios igual de «exóticos» como Hungría, Polonia o Rumania ${ }^{11}$. En ese sentido, lo checoslovaco aparece como cifra de todo un sistema de imagotipos más amplio y no restringido a las tierras checas, en el que «lo eslavo» (el «otro europeo») parece oponerse con su extrañeza, exotismo y marginalidad al ámbito más familiar y conocido de Europa. Lo interesante es que ese imagotipo que se construye como hilo conductor entre extranjería, marginalidad y rareza aparece en varias obras importantes de la literatura argentina, como por ejemplo en la figura de Tardewski en Respiración artificial, a manera de clave para acceder a ese componente múltiple e indescifrable de la propia identidad nacional, escindida entre lo europeo y lo latinoamericano. Sin embargo, ese intento por dirimir la imagen propia en la de un tipo de extranjero más exótico se manifiesta, en estos dos relatos, de una forma completamente distinta: mientras la inclusión del personaje checoslovaco en el cuento de Abelardo Castillo parece remitir a cierta búsqueda de lo universal, a tono con el clima revolucionario de su época, y, a la vez, responde a la trama misma del relato y la necesidad del narrador

10 El ingeniero del tornillo filoso.

11 En La ciudad ausente de Ricardo Piglia aparece esa misma indeterminación cuando se dice de uno de los personajes que «lo llamaron el ruso, pero parece que era húngaro o checoeslovaco, y cuando estaba borracho juraba que había nacido en Montevideo». 
de aceptarse a sí mismo; la crueldad sin atenuantes y caricaturesca del checoslovaco de Laiseca, vinculada a la clausura de los canales de comunicación, no deja de hacer referencia, aunque de una forma sinuosa como es típico en su obra, a la violencia sistemática del Estado que se inicia ya durante el tercer peronismo con los crímenes paramilitares de la Triple A y llega a su punto máximo durante la última dictadura militar, que terminaría marcando un antes y un después en la historia argentina.

\section{Referencias bibliográficas}

Aira, C., Exotismo, Boletín del Centro de Estudios de Teoría y Crítica Literaria 3, 1993, pp. 73-79.

Beller, M., leerssen, J., Imagology: The Cultural Construction and Literary Representation of National Characters: A Critical Survey, Amsterdam 2007.

Borges, J. L., Discusión, Buenos Aires 1932.

Castillo, A., Cuentos completos: Los mundos reales, Buenos Aires 2003.

Castillo, A., «Vale decir», Página/12, entrevista por J. P. Bertazza, Buenos Aires, 18 de diciembre 2011.

Conde de Boeck, A., El monstruo del delirio, Trayectoria y proyecto creador de Alberto Laiseca en el campo literario argentino (1973-1998), Buenos Aires 2017.

Drucaroff, E., Los prisioneros de la torre, Buenos Aires 2013.

Gilda, C., Entre la pluma y el fusil. Debates y dilemas del escritor revolucionario en América Latina, Buenos Aires 2003.

Laiseca, A., Matando enanos a garrotazos, Buenos Aires 2004.

Laiseca, A., El jardín de las máquinas parlantes, Buenos Aires 2013.

Lecercle, J. J., The Violence of Language, London/New York 1990.

Leerssen, J., National Thought in Europe, Amsterdam 2016, p. 29.

Moreno, C. F., América Latina en su literatura, México 1973.

Pérez Gras, M. L., La imagología de cara al presente a la luz de la hermenéutica analógico-contextual: el caso de la construcción imagológica del aborigen en la literatura argentina, Enfoques 30/2, pp. 39-65.

Piglia, R., Respiración artificial, Buenos Aires 1980. Texto en formato electrónico Kindle.

Piglia, R., La civilización Laiseca [Buenos Aires: Simurg, 1998], prólogo a Los sorias, Buenos Aires 2004, pp.7-10.

Prieto, M., Breve historia de la literatura argentina, Buenos Aires 2016.

Sánchez, P., La emancipación engañosa. Una crónica transatlántica del boom (19631972), Alicante 2009. 


\section{Construcción y funcionalidad del inmigrante en los relatos "El candelabro de plata» de Abelardo Castillo y «El checoslovaco» de Alberto Laiseca}

Palabras clave: exotismo, inmigración, extranjería, marginalidad, crueldad, lenguaje

Este artículo se propone indagar de qué forma y con qué objetivo es abordada la figura del inmigrante checoslovaco en los correspondientes relatos de dos importantes escritores argentinos que pertenecen a un período muy distinto del campo literario argentino: «El candelabro de plata» (1961) de Abelardo Castillo y «El checoslovaco» (1982) de Alberto Laiseca. Aunque un primer elemento en común que se advierte es cierto exotismo asignado a los protagonistas, se analizarán también las diferencias entre ambos personajes y propuestas estéticas con el objetivo de inquirir qué puede llegar a señalar, en cada caso, esa construcción del extranjero checoslovaco acerca del contexto literario y político en el que se originaron ambas obras.

\section{Izoblikovanje in funkcionalnost priseljenca v kratkih zgodbah El candelabro de plata Abelarda Castilla in El checoslovaco Alberta Laisece}

Ključne besede: eksotizem, imigracija, tujstvo, marginalnost, krutost, jezik

Članek raziskuje, kako in s kakšnim namenom je obravnavan lik češkega priseljenca v dveh kratkih zgodbah pomembnih argentinskih pisateljev: v Candelabro de plata (Srebrni svečnik) (1961) Abelarda Castilla in El checoslovaco (Čehoslovak) (1982) Alberta Laisece. Čeprav je prvi skupni element, ki se opazi, določen eksotizem, ki se pripisuje junakoma, avtor prispevka analizira tudi razlike tako med njima kot med pripovednimi estetskimi prvinami, da bi ugotovil, kaj lahko takšno izoblikovanje češkoslovaškega tujca $\mathrm{v}$ teh dveh primerih pove o literarnem in političnem kontekstu, $\mathrm{v}$ katerem sta nastali deli. 
JuAN PABlo Bertazza / CONStRUCCIÓN Y FUnCIONALIDAD DEL INMIGRANTE EN LOS RELATOS

«El Candelabro de Plata» de Abelardo Castillo y «El Checoslovaco» de Alberto laiseca

\section{The construction and function of the immigrant in the stories "El candelabro de plata" by Abelardo Castillo and "El checoslovaco" by Alberto Laiseca}

Keywords: exoticism, immigration, foreigners, marginality, cruelty, language

This article aims to investigate how and with what objectives the figure of the Czechoslovakian immigrant is represented in two comparable stories by two major Argentine writers who, despite having been contemporaries, are considered to belong to very different periods of Argentine literature: "El candelabro de plata" (1961) by Abelardo Castillo and "El checoslovaco" (1982) by Alberto Laiseca. Although the two stories share a superficial point in common in that the immigrant is exoticized, there are key differences between not only the characters but also the style and aesthetics of the works. The paper analyzes these differences in order to try to understand what the construction of the Czechoslovakian foreigner in each case can reveal about the literary and political context in which both works originated.

\section{O avtorju}

Juan Pablo Bertazza je diplomiral iz književnosti na Univerzi v Buenos Airesu. Zdaj je doktorski študent na Univerzi Palackega v Olomucu in raziskuje zapise argentinskih avtorjev o elementih, povezanih s češkim/češkoslovaškim kulturnim območjem. Objavil je romana Síndrome Praga in Alto en el cielo (Visoko na nebu) (Adriana Hidalgo) in sodeluje z Radiem Prague International, argentinskim časopisom La Nación in mehiško revijo Nexos.

E-naslov: juanpablobertazza@gmail.com

\section{About the author}

Juan Pablo Bertazza has a Bachelor's Degree in Literature from the University of Buenos Aires. He is currently doing a PhD in Literature at Palacký University Olomouc, Czechia on how Argentinian authors portrayed Czechia / Czechoslovakia and reworked aspects of its culture. He has published two novels - Síndrome Praga and Alto en el cielo (Adriana Hidalgo) - and also contributes to the Argentine newspaper La Nación, Radio Prague International and the Mexican magazine Nexos.

E-mail: juanpablobertazza@gmail.com 